\title{
DISCURSOS Y PRÁCTICAS DE DES-PROTECCIÓN EN EL TRANSTIERRO. TRANSITAR (DESDE) LOS BORDES: EL BUEN DOLOR DE GUILLERMO SACCOMANNO
}

\author{
POR \\ ESMERALDA BROULLÓN-ACUÑa ${ }^{1}$ \\ Universidad de Cádiz
}

A MODO DE INTRODUCCIÓN: GiRo SUBJETIVO Y ESCRITURA DESDE LOS MÁRGENES

El siguiente ensayo se encuadra en el marco de un estudio mayor acerca de la configuración identitaria del sujeto transterrado en el periodo de entre siglos, XX y XXI. Por ello nos adentramos en la introspectiva memorialística e historiografía de la cultura narrativa rioplatense, ahondando en sus posibilidades metodológicas en cuanto trasunto de la realidad.

La construcción de la nación argentina fue conformada por la inclusión de identidades preseleccionadas, no sin fricciones, de ahí la histórica dicotomía entre "civilización/ barbarie" en la articulación de la identidad nacional junto con la exclusión de los propios elementos culturales; o lo que es lo mismo, el proceder constitutivo de una Europa en la Argentina que censuraría como bárbaro lo propio y exaltaría en civilizado lo ajeno. Sin embargo, el inverso fenómeno diaspórico ha originado un proceso transculturador que permite resemantizar lo propio como lo ajeno hábilmente hilvanado en la discursividad migratoria contemporánea. Un puente o corredor trasatlántico conecta ambas orillas euroamericanas sobre el espacio y el tiempo. De ahí nuestro interés por los usos discursivos y los modos de representación que tienden a la hibridación cultural.

$\mathrm{Al}$ hilo de los estudios que venimos realizando acerca de la escritura testimonial sobre el transtierro y la transnacionalidad, tomamos como pre-texto la obra del escritor argentino Guillermo Saccomanno, titulada El buen dolor (1999). ${ }^{2}$ Ya que su estructura indaga en la intrahistoria como en la historia de este fenómeno propio del ser humano que es la movilidad, desde las esferas privada (la familia) y pública (el Estado). En

\footnotetext{
Este trabajo se inserta en el marco de una investigación financiada por el Ministerio de Economía y Competitividad del Gobierno de España, bajo el título: Política, discursos y prácticas de protección al migrante. El caso de los españoles en Argentina y Brasil. HAR2012-33147.

2 En este texto nos referiremos a la segunda edición de la novela (Saccomanno 2008).
} 
ella se refleja la autopercepción del autor/protagonista en un universo particular, el modo en que éste interpreta el mundo, su cosmovisión en un contexto histórico determinado. La interdiscursividad del escritor argentino subvierte el canon en una especie de hibridación narrativa y cultural donde espacios autobiográficos y relatos retrospectivos dan cuenta de las historias narradas.

La obra de Saccomanno -profundamente imbuida de su experiencia vital- está trazada sobre unas coordenadas políticas concretas en conexión con el quehacer sociohistórico euroamericano acaecido durante el siglo XX. Bajo unos acontecimientos propicios el protagonista de este documento "ficcional" dialoga reafirmando o alterando su identidad pero conquistando en definitiva un valor destacado, al tomar conciencia de su individualidad. Para ello su creador maneja los giros sintácticos, propios del personaje, con hábil maestría, aunando realidad y ficción y mostrando un absoluto dominio del discurso narrativo. Desde la intimidad recreada interpela al mundo exterior. El buen dolor como modalidad autobiográfica y género del yo por excelencia se erige en una práctica introvertida, donde un sujeto omnipresente dialoga condicionado por sus circunstancias como individuo desplazado. En esta coyuntura el detalle pormenoriza su escritura, pero sobre todo el autor compone un espacio privilegiado donde resistir el olvido y trascender la muerte, aludiendo a una permanencia ontológica.

Guillermo Saccomanno(Buenos Aires, 1948) es un autor consagrado en el panorama narrativo actual. Ha sido agente publicitario, guionista de historietas y ha transitado géneros marginales como son los cómics. Entre sus obras cabe mencionar Partida de caza (1979), Prohibido escupir sangre (1984), Situación de peligro (1986), Roberto y Eva. Historias de un amor argentino (1989), Bajo bandera (1991), Animales domésticos (1994), La indiferencia del mundo (1997), El buen dolor (1999), El oficinista (2010), y Cámara Gesell (2012). A lo largo de su carrera ha obtenido diversos galardones, entre ellos el Premio Nacional de Literatura, el Premio Municipal de Cuento, el Premio Crisis de Narrativa Latinoamericana y el Premio Club de los XIII. Con su penúltima obra, El oficinista, logró el Premio Biblioteca Breve 2010, concedido por la editorial Seix Barral de Barcelona, mientras que Cámara Gesell fue galardonada en el 2013 con el Premio Hammett de la Asociación Internacional de Escritores Policiacos, fallado en el marco del festival literario y multicultural de la Semana Negra de Gijón.

El escritor y periodista argentino cuenta con un texto narrativo que podríamos adscribir al género de cuentos, vinculado al fenómeno del transtierro, mediante el cual obtuvo el Premio Nacional de Literatura: El buen dolor. El título de la obra alude a la novela inédita del padre de Guillermo Saccomanno, titulada El buen combate. No obstante su progenitor fue evocado por primera vez en otra de sus novelas Situación de peligro (1986), escrita con anterioridad a El buen dolor (1999). El protagonista de esta última, alter ego del escritor, disecciona en qué consiste el (buen) dolor, en clara alusión a la experiencia que soportan los personajes en unas circunstancias límites. Un dolor amortiguado pero sobre todo transformado - el buen dolor- por el pensamiento

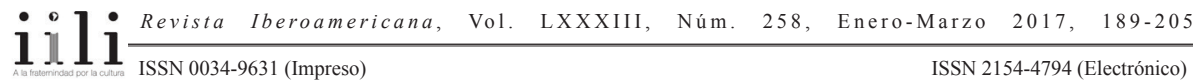


judeocristiano así como por los valores del trabajo y el sacrificio en el marco de la gran emigración hispano/italo-argentina representada en el texto.

En cuanto a la elección del enfoque, etnohistórico y etnoliterario de nuestro ensayo para el estudio de los contactos y transferencias culturales entre ambas orillas atlánticas, radica en el propio alcance antropológico que adquiere el mismo. ${ }^{3}$ En especial por el modo en que se articula la memoria y las condiciones de producción de la escritura memorialística y testimonial. Entre los tipos de escritura autobiográfica pueden encontrarse diversas formas narrativas como la auto/biografía, el autorretrato, la novela autobiográfica, las memorias, los libros de viajes, los epistolarios o los dietarios y diarios. Hemos abordado la escritura autobiográfica y memorialística como espacio para el reconocimiento del yo. ${ }^{4}$ Una narrativa de fronteras donde se desdibuja la confrontación entre realidad/historia y ficción. De ahí nuestro interés por los usos del lenguaje y los hilos de su entramado en la construcción social de la realidad.

La Autobiografía ficcional y el deSdoblamiento del yo en Guillermo SaCComanno: EL BUEN DOLOR

El buen dolor es una novela breve que, bajo unas coordenadas históricas, ahonda en la intrahistoria de una familia de origen hispano-italiana, tras el desenlace fatídico de la muerte del padre y el tumultuoso acontecer sociopolítico argentino del siglo XX. Intrahistoria, historia, narrativa de frontera, autobiografía, familia, estado y diversos aspectos de la cultura migratoria hispano/italo-argentina conforman el eje estructural de esta obra. Resulta complejo concluir acerca de una única línea argumental de la novela, si bien este es un texto sobre viajes y territorios fronterizos, donde el protagonista alter ego del novelista - transita entre los límites de la desesperación y la conquista de la justicia social. En ella hace un ejercicio de memoria selectiva sobre su experiencia vital, ${ }^{5}$ describiendo la situación de pobreza familiar tras la enfermedad acaecida en dos de sus miembros: la abuela y el padre. A partir de sus propias circunstancias

3 La etnoliteratura como método de análisis antropológico cobró relevancia en las ciencias humanas y sociales al tomar como referencia el modelo semiótico de la cultura, respecto a los "juegos del lenguaje", con la finalidad de explorar las dimensiones más recónditas del ser humano. El ámbito literario, concebido como discurso y práctica social, se transcribe como una forma de experiencia y su estatuto textual -la escritura- como la representación del mundo imaginario/real, contextualizado en un determinado marco sociohistórico. Este planteamiento metodológico complementaría el proceso etnográfico y la información obtenida en el trabajo de campo, desacralizando este último como único instrumento para el conocimiento antropológico. La etnoliteratura como método de análisis antropológico ha sido abordado por Antonio Jiménez Nuñez y Manuel de la Fuente Lombo.

4 Sobre teoría y metodología de la historia autobiográfica, sirva de referencia Loureiro; Broullón.

5 El debate acerca de la experiencia personal como fundamento sostenedor en "la construcción de la verdad" ha sido analizado por Sarlo (Tiempo pasado).

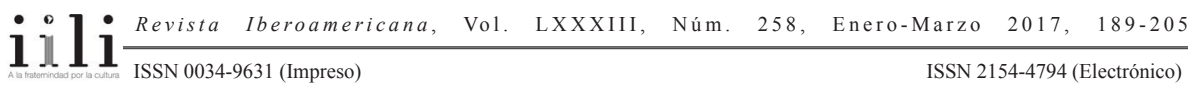


personales el autor recompone un texto político, pues en realidad contextualiza una historia colectiva desde la propia intimidad. Trazada con precisión y estilo propio, es intencionadamente testimonial ya que su trama mantiene una estrecha referencia autobiográfica. Bajo este prisma el escritor transita en una narrativa de fronteras que tiende a la "narrativa del yo autobiográfico". ${ }^{6}$ Mientras que testimonia la experiencia, enfatiza una época -mediante el recuerdo- fuertemente remarcada por lo histórico y cultural, revelando en consecuencia determinados acontecimientos públicos del país receptor y emisor de sus antepasados, originarios de España e Italia y transterrados en la Argentina como migrantes.

Los personajes que componen la historia deambulan por los resquicios de su existencia, por lo que una hondonada de marginalidad inunda los recovecos de la trama. Entre la ficción y la realidad, aunque el autor -al igual que otros grandes creadores de ambas orillas atlánticas- ha declarado en diversas entrevistas sobre la obra que "esto no es literatura"; Saccomanno construye un breve pero penetrante relato sobre la (su) familia y el imaginario sociopolítico argentino en el siglo XX. ${ }^{7}$ Éste inquiere con acertada lucidez en las instancias familiares y gubernamentales, a través de los vaivenes del Estado, pues ambas reproducen un sistema de autoritarismo y represión, temas que envuelven la obra. Los protagonistas de El buen dolor están subordinados a distintos marcos opresores, y actúan desde los confines de la sumisión. Las relaciones familiares circulan sometidas al ejercicio de la autoridad de la abuela. A pesar de la ambigüedad y los límites fronterizos de la noción de autoridad ${ }^{8}$ ya que ésta replantea unas relaciones de obediencia a la hora de regular las relaciones humanas, habría que matizar, hecho en el que repara Saccomanno, las condiciones en las que ésta surge. Pues son las mismas que llevan al padre a rechazarla, en primera instancia -entendiéndola además como un anacronismo-; sin embargo al progenitor no le queda otra opción que replegarse a la obediencia de ésta. No obstante para la matriarca que es la abuela, la autoridad está cimentada en el marco de la tradición, y es concebida en cambio como un modelo ordenador frente al caos y el anarquismo del yerno. Pero la autoridad, expuesta en la novela no deja de practicarse como un elemento anexionado a la historia del patriarcado que, institucionalizándose en lo social, se convierte en una forma de poder.

6 El componente memorialístico y autobiográfico configuran la médula de unos fragmentos escritos en los límites del realismo y que es trascendido mediante la ficción. Mientras que las formas verbales, conjugadas entre el tiempo pasado y presente, inducen a un mismo tiempo a la revelación y la invención narrativa. Así el autor nos trasmite magistralmente el imaginario de una cultura de inmigrantes hispanoitalianos en distintos periodos políticos de la historia contemporánea argentina.

7 Continuos trazos fronterizos demarcan la narrativa de Saccomanno y en especial, entre la historia y la intrahistoria; la familia y el estado, el escritor reaviva la memoria colectiva de la nación a partir de una experiencia individual.

8 La categoría de autoridad ha sido revisada a partir de los presupuestos expuestos en Arendt ("¿Qué es la autoridad?”; Los orígenes del totalitarismo); Birulés; Derrida; Bochenski; Muraro; Sennett. 
Otro aspecto interesante es que Guillermo Saccomanno nos aproxima a los modos en que se despliega el poder gubernamental sobre la población. La vida de los seres humanos está reglamentada mediante políticas estatales que influyen en éstos de manera decisiva, mientras que a través de determinadas reglamentaciones se regulan exigencias y modos de ser sobre la misma. Bajo este proceder, la obra nos transfiere el imaginario colectivo de un país que ha sido modelo de empresa migratoria para la construcción nacional. Ahora bien lo que insta decir es que las formas de control que se barajan en el texto se ejercen particularmente sobre sectores de la población al emitir normas jurídicas, normalizadoras y penalizadoras, como son aquellas que se ejercen, entre otras, sobre el matrimonio y determinados modos de cohabitación orientados hacia una concreta organización familiar, tan elocuente en El buen dolor. De este modo se fomentan delimitados comportamientos en el seno de las relaciones sociales que llegan a ser institucionalizadas como "idóneas", es decir, favorecedoras o sostenedoras de una división del trabajo dentro de la familia. Dicho de otro modo, el texto advierte sobre la organización social, la estructura ocupacional y segregacionista de la población, de los colectivos migrantes en especial; mientras que la legitimidad de un "salario familiar" articula la vida en sociedad, perpetuada por los aparatos ideológicos estatales (Althusser).

Bajo estas premisas, Saccomanno aborda -desde la intrahistoria familiar- una historia colectiva, a la vez que reflexiona sobre la fragilidad humana. Cuando el escritor rememora la historia de su padre e indaga en el dolor psicofísico sobrevenido, ${ }^{10}$ examina con verdadera maestría el lado oscuro de la realidad impuesta. Con ello no sólo "lava su ropa" sino toda la sábana social, al mismo tiempo que expresa la imposibilidad de su total exteriorización narrativa, trasladándonos en repetidas ocasiones a los límites fronterizos entre realidad y ficción. Pues cuando la narración se separa del cuerpo, la experiencia se separa de su sentido (Sarlo 33).

El texto, breve en su composición pero solemne en el contenido, recorre de manera circular, en una acumulación superpuesta de fragmentos independientes, la segunda mitad del siglo XX. Si bien irrumpe con el imaginario migratorio de una

9 El salario familiar ha sido un hecho central en la historia social en general y de la historia del obrerismo en particular-de mediados del siglo XIX y principios del siglo XX-. Su consolidación como tal facilitó la legitimación de unos salarios complementarios a las trabajadoras. Bajo esta ideología, el trabajo femenino fue apartándose del mercado, erigiéndose un hecho operativo para el capital. Es decir, el otorgar a un sistema productivo la inclusión de un salario familiar sirvió de fundamento para legitimar la idea de "ayuda" aportada por las mujeres. La aparición del salario familiar, sostiene Celia Amorós, fue posible por la existencia de lo que denomina "pacto patriarcal interclasista" (43). En una misma línea Anna Jónasdóttir, en su crítica a Heidi Hartmann, entiende este sistema -el patriarcado- como la "alianza de los hombres por encima de las fronteras de clase" (86).

${ }_{10}$ Cabe mencionar que la figura del padre reaparecerá de manera significativa en la narrativa memorialística argentina reciente. 
saga hispanoitaliana en la Argentina durante el primer cuarto de siglo y el contraste memorialístico de un niño fascinado por las imágenes de la revista Life. Con un tono confesional, aunque alejado del diario íntimo, la historia está narrada con la apreciable distancia que permite trazar una frontera entre la ficción y la autobiografía, traspasada de manera permanente por el protagonista. Pequeños relatos circundan la misma, reencontrándose en diversos momentos de una historia narrada en primera, así como segunda -en un desdoblamiento de la primera- y tercera persona, adoptando un considerable distanciamiento testimonial.

El buen dolor es una fábula "exhibicionista" que con un estilo tajante y directo se repliega sobre una denuncia. En ella, las injusticias sociales se codean con las circunstancias que acompañan el dolor y el desánimo que origina la pobreza y la enfermedad en una familia de condición "humilde", aludiendo a la fractura de clase como marcador de identidad personal. En esta coyuntura la representatividad del cuerpo sobresale como la materia prima del relato. La obra transmite la fuerte presencia de la naturaleza corporal de la vida humana, es decir, el cuerpo se representa como objeto de conocimiento, franqueado a través del discurso narrativo y sus fronteras, exponiendo el modo en que se insertan en él prácticas de poder. Desde su perspectiva, Saccomanno rescata la dimensión política de la corporeidad humana, al exponernos entre otros aspectos de un cuerpo social y político des/arraigado, doliente; e incorpora el peso de las estructuras políticas, sociales, culturales y económicas opresivas, lo cual nos ayuda a comprender la posición de los sujetos en cuanto a seres sexuados y su constreñida interacción sociohistórica con el medio. Es decir, nos muestra el cuerpo como objeto político, entendido como un territorio para el ejercicio y la regulación del poder. ${ }^{11}$

El autor rememora los orígenes familiares y la casa paterna, evocando los sentimientos entrecruzados entre sus miembros y las circunstancias políticas que les acompañaron en la sociedad receptora, a saber, laArgentina contemporánea desde la gran emigración a la época actual. Pero lo hará huyendo de la melancolía y el acicalamiento del pasado, revelando que no todas las historias familiares son el centro ilusionista de un universo literario. Dicho de otro modo, Saccomanno ahonda en el paraíso terrenal, aproximándonos a diversos aspectos de la segregación poblacional migratoria, en una clara alusión deconstructiva del judeo-cristianismo. Muerte, pobreza, desarraigo identitario son temas barajados en su breve novela. Aunque el dolor exorcizado en

${ }^{11}$ Enfoque proseguido desde las premisas foucaultianas ya que para Michel Foucault, desde los siglos XVII-XVIII el gobierno utilizó el ejercicio del poder mediante determinadas técnicas que construyen los territorios de poder-saber. A partir del sujeto entendido como un cuerpo adiestrable y la población como una máquina de producción, utilizó los conceptos de anatomopolítica y biopolítica. Los anteriores sujetos jurídicos serían concebidos como cuerpos y poblaciones, mientras tanto, el poder ejerce su acción contra el cuerpo con el objetivo de conseguir su normalización. De este modo, el cuerpo se convierte en un producto de poder mismo. Véase al respecto, Foucault. 
este relato tan circunspecto irradia fuerzas beligerantes y contenidas en la ficción, diseccionando las relaciones de poder en la sociedad y en la familia.

\section{LA FAMILIA Y EL ESTADO EN LA CULTURA DIASPÓRICA HISPANO/ITALO-ARGENTINA}

El buen dolor es una obra breve pero densa, estructurada en base a tres relatos. La primera parte, concebida bajo el título "escribir", despunta en el año 1959. Describe la infancia y la adolescencia del protagonista identificado como G., que junto a su familia reside en un barrio humilde de Buenos Aires, "entre" Floresta y Mataderos, aludiendo desde el inicio a la representatividad de las fronteras físico sociales del espacio urbano, lugar receptor de inmigrantes. En ella, el interlocutor (G.), posicionado en una segunda persona, ${ }^{12}$ rememora, en alusión al protagonista principal (G.), la vida cotidiana de éste en una modesta casa construida por los abuelos, inmigrantes gallegos. Ahonda en la composición del grupo familiar y sus condiciones materiales de existencia: constituido por el padre (de origen italiano), la madre (de origen español), la hermana y por último la abuela (inmigrante gallega), matriarca del clan familiar y autoridad férrea de la unidad doméstica quien administra la casa con "mano de hierro".

Novela de fronteras, enfatiza la territorialidad limítrofe y la segregación poblacional de un barrio de inmigrantes, ahondando en los diversos marcadores diferenciales de sus moradores. Una diferencia que socialmente se percibe en escalas enmascaradas:

Esa era la única casa del barrio, situada en el límite entre Floresta y Mataderos, a la que llegaba el Life en inglés. Papá la compraba para vos. Porque vos eras el único pibe de esa cuadra que estudiaba inglés. Mamá decía que la casa estaba en Floresta, pensando en decir Floresta y no en Mataderos podía hacer diferencia [...] Aun cuando tu familia no estaba todavía en la pobreza, sino que pertenecía a ese sector que se denominaba hipócritamente gente humilde... (16)

Un halo de homogeneidad y precariedad sostenida caracterizan al barrio que toma vida en las líneas expresivas del escritor argentino. Las primeras casas, construidas de chapa y madera como testigo fiel de los orígenes de sus habitantes, fueron transformándose a medida que se introdujo el progreso que acompañó al ladrillo. El hábitat, constituido por varias piezas sucesivamente adosadas con el tiempo incluye un pequeño huerto que abastece a la familia, aludiendo al modo de vida de origen

12 La historia es narrada por una segunda persona no identificada que rememora frente a un oyente -el protagonista de la novela- la historia familiar de este último y su propia trayectoria en el círculo íntimo de los parientes y a quienes menciona en el texto: papá, mamá, la abuela... En el marco descrito el uso de la segunda persona tiende aludir a un desdoblamiento del propio personaje, quien en realidad evoca para sí su propia biografía. El desdoblamiento del yo autobiográfico en Saccomanno ha sido expuesto por Cárcamo. 
rural. Del mismo modo que la progresiva ampliación de la casa mantenía la función de amortiguar la economía doméstica mediante las reservas obtenidas por el alquiler de una habitación para huéspedes, recién instalados en la ciudad. La propiedad del terreno junto con la morada en la que cobijarse componen el legado de esta familia de inmigrantes hispanoitalianos arribados a la Argentina a principios del siglo XX, a la cabeza de la matriarca de origen gallego, secuenciando un convulso periodo político que oscila entre la adaptación y el sometimiento bajo un halo de anarquismo:

Casi todas las casas del barrio eran iguales [...] La mayoría, habitadas por inmigrantes italianos y españoles que, en los años veinte, con unas pocas chapas y la madera de las cajas de embalaje de automóvil importado, habían levantado primero una barraca. Comprados, juntados por ahí cuando no robados, los ladrillos vinieron después. Así habían edificado [...] Más tarde, iban adosando piezas a la estructura primitiva.

La casa en la que vivías no era distinta. Tenía un jardín y una huerta a la entrada [...], la abuela había hecho levantar dos cuartitos de madera y chapa, que alquilaba a unos mendocinos recién casados. Detrás estaba el gallinero.

[...] Papá era sastre. Le disgustaba su oficio. Quería ser escritor. Había estudiado periodismo [...], papá participaba de la oposición al peronismo. Con las ideas no se come, le decía la abuela. Según la abuela, papá era el culpable de nuestras estrecheces. Ser la dueña de la casa le confería prerrogativas. Usted va a terminar como ese anarquista, le pronosticaba amenazadora. Preso de por vida en Tierra de Fuego. (18-19)

En circunstancias adversas los personajes se repliegan sobre sí ante la estrechez de las contingencias más tarde sobrevenidas, precarizándose sus condiciones materiales y oportunidades. Bajo este panorama, Guillermo Saccomanno narra una intrahistoria punzante de la institución familiar en la literatura, mostrada por lo habitual de manera ilusionista. ${ }^{13}$

La novela disecciona las relaciones sociales acontecidas en el ámbito doméstico cuyos vínculos, que actúan como frágiles pilares, se asientan en un sistema matrilineal que no es matriarcal. ${ }^{14}$ Mediante la experiencia narrada, sintetiza las pautas de una familia gobernada por la abuela materna, acérrima defensora del trabajo y de la casa. Protectora y administradora de la misma, ésta se erige como un histórico personaje que logra su parcela de certidumbre en el territorio de la inmigración, gracias al sacrificio de su oficio como lavandera y sirvienta junto con el finado de su marido, panadero de

13 Para una aproximación sobre el estudio de la institución familiar latinoamericana desde el planteamiento expuesto, sirva de referencia Robichaux.

14 Transmisión del parentesco sólo por la línea femenina, mientras que el matriarcado sería el régimen político donde el poder estaría en manos de las mujeres, no conociéndose ninguna sociedad que haya vivido bajo este principio. Para una aproximación a las comunidades cuyos grupos domésticos están encabezados por mujeres, véase Brown; Kuper; Rosaldo y Lamphere; Smith.

$111 \frac{\text { Revista Iberoamericana, Vol. LXXXIII, Núm. 258, Enero-Marzo 2017, }}{1189-205}$ 
profesión en el lugar de acogida. Su concepción de "ayuda mutua y colaboración" entre todos los miembros del grupo doméstico, frente a tanta constricción externa, predispone al sacrificio del individuo en favor de la colectividad familiar. Es decir, la autoridad de la abuela reproduce una concepción de la familia sostenida sobre la cooperación, que refuerza la identidad social del grupo y la cohesión de "la casa"; para así mantener una función reguladora y mediadora de los conflictos, en este caso exacerbada. En otras palabras, la sociedad de acogida se estructura sobre la familia, entendiendo ésta como unidad económica de producción y consumo amortiguada por una manda matrilineal, o sea por la fuerte presencia femenina. Dispositivo frente al desamparo que reutiliza la abuela para ejercer su dominio en el microcosmos doméstico.

La posición de privilegio que goza la anciana dentro del grupo la llevan a ejercer su dominio y especialmente a humillar al yerno a quien concibe como un parásito social: hombre ilustrado e hijo de inmigrante italiano, sin oficio ni beneficio estable, soñador y utópico. ${ }^{15}$ A quien paradójicamente acosa por carecer de los valores patriarcales, acordes con la legitimidad de masculinidad en el seno familiar en institucional. Los pares contrapuestos por el perfil desdibujado de estos dos miembros de la unidad doméstica hilvanan el argumento de gran parte de la historia:

Como papá trabajaba en casa, su situación se volvía más humillante [...] Como en la sastrería, frente al pompier, papá agachaba la cabeza. Por favor, suplicaba mamá, ¿qué van a decir los inquilinos? Entonces la abuela cedía. Apreciaba más a los inquilinos que a papá [... Papá abandonaba la mesa. Salía dando un portazo que hacía temblar los cimientos de la casa. Si mamá quería seguirlo, la abuela la retenía: Ya volverá, garantizaba. Si el pobre desgraciado no tiene donde caerse muerto. Porque los ideales no dan producto... (21)

El padre de G., sastre de profesión y conocedor de la esclavitud del taller, labora en casa. Por consiguiente, la historia contextualiza la precariedad y los prejuicios del trabajo "doméstico" -masculino- frente a los valores imperantes, reproducidos por la separación del espacio público del privado (Yanagisako; Rosaldo "Mujer, cultura" y Knowledge and Passion). En este sentido, resulta paradójica la posición paterna en el marco de la institución familiar, pues si nos remitimos a los antecedentes de la escisión, por un lado, de la familia como el ámbito de lo doméstico, y por otro lado el de la pura economía como ente (público), segmentando los espacios en privado y

${ }^{15}$ El discurso que defiende la abuela en torno al trabajo ahonda en un determinado comportamiento, representaciones, valores así como actitudes precisas que responden a la cultura del trabajo como inmigrantes de origen gallego y que el yerno transgrede. Para la anciana, renta familiar y trabajo familiar forman parte de una red de derechos y obligaciones al hilo de la relación de sexos y generaciones expuesta en la narrativa de Saccomanno. De tal manera que la familia es representada como un medio de opresión. 
público para hombres y mujeres, el padre de G. se sitúa en la ambigua frontera de un espacio doméstico, y ejerce además un oficio concebido en determinadas circunstancias como femenino. Asimismo el dominio de lo productivo sobre lo reproductivo lleva en este ejemplo a mostrarnos la politización que existe en la vida cotidiana. Ahora bien, estimamos que el espacio en sí mismo no otorgaría poder sino más bien la actividad que se concreta como masculina/femenina, en función a unos sistemas culturales que proporcionan autoridad (Rosaldo, "Mujer, cultura y sociedad" 155). Éste, alejado de la fábrica, se encuentra sometido al dominio de la servidumbre familiar (parentesco), asimilando su oficio al del trabajo domestico, siendo doblemente estigmatizado/ feminizado por el origen de su actividad como por el lugar donde lo desarrolla:

Pero papá no era feliz del todo mientras tuviera que ganarse el pan con este oficio. En sus momentos de tristeza decía que éste era un oficio femenino. Terminaba por destruir el alma y el cuerpo.

[...] Había conocido, decía, la esclavitud de los talleres [...] Ni te cuento los que trabajan, como yo, a domicilio, encerrado en su soledad, escuchando óperas. (25)

Sin embargo el relato de Saccomanno muestra a un hombre soñador y tenaz frente al infortunio y la injusticia social. Su verdadera vocación es el periodismo y la escritura cuya fuente de inspiración son los escritores naturalistas del siglo XIX. Oficio que mantiene continuamente relegado, entre otros motivos, por contrariar a los regímenes secundados en cada coyuntura histórica de la Argentina. Orador y polemista permanece como opositor político, manifestándose especialmente contrario al peronismo y los sucesivos relevos, por lo que es amonestado, primero por la suegra y más tarde por las instancias gubernamentales, es decir por la familia y el Estado:

Según papá, la abuela era como el estado. En nombre del bien la abuela producía el mal. Algo en ella misma, quizá la conciencia de su poder, incitaba a la rebelión (...) Por eso papá sostenía que Perón cuando hablaba del estado de los trabajadores, hablaba en realidad, como fascista que era, de la defensa de la propiedad privada. (...) Si se dinamitaba a Perón, se dinamitaba a ambos a un tiempo. (22)

Por su parte, la figura de la madre es invisibilizada y mermada en su capacidad de decisión. ${ }^{16}$ Hija única de inmigrantes gallegos en la Argentina, se recibe de perito mercantil, si bien el oficio que desempeña es el doméstico; aunque su voluntad en el

16 Mientras que la familia no se erige como proyección luminosa de la novela, la figura de la madre es desplazada en el papel rememorador de la propia historia, contrariando el peso otorgado a dichas prácticas femeninas en las narrativas hispanoamericanas. Respecto a esto último, véase Molloy ( $E l$ común olvido). 
ámbito privado/doméstico esté continuamente cercenada por la autoridad materna, conteniéndose en un segundo plano frente a las disputas familiares:

Mi hija no es su compañera. Es su esposa. Pero antes de ser su esposa será siempre mi hija. Mirabas a mamá, asustada en un rincón. Papá también la miraba. De tener que elegir entre papá y la abuela, el miedo a la abuela habría decidido por mamá.

Si se levantaran de improviso todos los techos de la ciudad, te dijo papá después de una de esas grescas, si los hombres pudieran ver cómo viven, el mundo sería otro. Pero los techos no se levantaban. Y el mundo era esa casa. (28)

Tras la caída de Perón (1955) se sucede la decadencia familiar, pues la abuela enferma y agoniza lentamente a la vez que el hábitat se va devastando. Este es un episodio que el relato refleja con especial precisión a través de la descripción del entorno físico: en la casa se introduce el mismo estado corporal decrépito, el huerto se cubre de malezas, los inquilinos se marchan... mientras que el resto de las viviendas del barrio progresan, contrastando aún más la miserabilidad sobrevenida. Al mismo tiempo los sueños paternos se derrumban, pues su ilusión postergada de convertirse en navegante o escritor, una vez asegurada su posición económico-laboral, llega a su fin. Su condición como perseguido político lo reconvierte en peón portuario. En estas maltrechas circunstancias, G. logra un puesto de mozo en una empresa de publicidad, humillando aún más al padre: "Cuando volvías a casa por la noche, papá te recalentaba la comida y jugaban al ajedrez. Su sueldo como estibador era más bajo que el tuyo como cadete. Sin quererlo, vos también lo humillabas al ganar más” (28).

La madre, por su parte abandona definitivamente sus exiguas capacidades organizativas y domésticas, sumergiéndose en un desánimo sepulcral. Una vez fallecida la abuela, el espacio ocupado por la misma se transforma en un mausoleo y es el padre quien debe y puede tomar las riendas para tratar de reacomodar el páramo familiar. Entonces G. escribe su primer cuento mediante el cual trata de exorcizar su biografía ya que se hace imposible lograr el olvido de este episodio, trascender inmune al mismo, la cual marca la trayectoria del joven: ${ }^{17}$

El pasto y los yuyos cubrieron el jardín, sepultaron la huerta. La maleza flanqueó los árboles. Las paredes empezaron a ponerse grises, la pintura a descascararse. En el fondo, ya no estaba el gallinero, porque nos habíamos comido las gallinas. [...] En cada rincón de la casa la tristeza juntaba hongos, pelusa [...] En la cocina, la grasa era una capa oscura [...] En el baño, los azulejos blancos se volvieron verdes [...] Papá ya no te compraba el Life. Así que dabas vueltas las páginas de los números viejos. El tipo del Pontiac seguía pasándola fenómeno, como nunca. (36)

17 De ahí que esta novela contenga dos historias, una la de la familia y otra sobre las condiciones de producción del relato que irrumpe a partir del pronóstico reservado del padre. 
La segunda parte de la novela, titulada "Cenizas", está narrada en primera y tercera persona. En ella el relato se desplaza a un tiempo y un espacio que difiere del contextualizado en la primera parte: la ciudad balneario de Villa Gesell, aproximándonos a la trayectoria de otros personajes: G., el Francés, Inés. El autor realiza varios incisos temporales para hilvanar la historia, mientras que el protagonista (G.), en vísperas de la operación de su padre y con el pretexto de reescribir la historia familiar, viaja en pleno invierno a este lugar de la costa atlántica. El transcurrir del tiempo, la soledad, el papel de la narración en los límites entre la ficción y la realidad, el arte de contar y la historia oral adquieren protagonismo, a la vez que deslinda de nuevo las fronteras de los textos autobiográficos. No obstante el escritor reitera su postura alejándose de posiciones victimistas, es decir huyendo del sentimentalismo realiza un viaje interior cuando decide trasladarse de Buenos Aires a Villa Gesell:

Para eso están las historias. Para distraernos de la muerte [...] Al escucharlo ya no importa tanto lo que cuenta sino cómo lo cuenta. La verdad de lo que se cuenta, ha dicho alguna vez el Francés, poco o nada tiene que ver con la verdad de lo ocurrido [...] De la soledad venía hablando, dice. El que escucha necesita del cuento para sentirse menos solo en su desgracia. El que cuenta, por su lado, también busca compañía. [...] Pero el escritor no es personaje. Un escritor no puede ser nunca personaje. [...] El escritor, cuenta el Francés se considera a sí mismo ex-critor. (58)

En la estación de autobuses G. se reencuentra con Inés, a quien conoció tiempo atrás en sus "escapadas" a Villa Gesell por su relación con el Francés, dueño del hostal donde el protagonista suele alojarse y narrador de la historia en esta segunda parte, que incluye a G. Al igual que su compañero de viaje, esta es una mujer madura y fracasada en su sueño de actriz - el autor enfatiza la mediocridad de la misma- que cuenta con una trayectoria de vida que ha circundado los márgenes. Guillermo Saccomanno borda el perfil de unos personajes errabundos que en el duelo de su soledad se entrecruzan como ángeles caídos. La coincidencia de estos viejos conocidos airea la pesadumbre contenida en el relato de cada personaje.

En este tramo de la narración, G. viaja a Villa Gesell para desquitarse ante la operación del padre que se encuentra bajo pronóstico reservado, información que suministra como dato fehaciente para tratar de escribir su historia. ${ }^{18}$ Inés acude a la

${ }_{18}$ El protagonismo del padre en la autobiografía latinoamericana ha sido el eje estructural narrativo desde dimensiones tanto privadas como públicas, donde la intrahistoria y la historia se han entrecruzado con afinado tratamiento en el desarrollo literario. Dimensión abordada por Ludmer; Molloy (Acto de presencia); Cárcamo. 
ciudad balneario para revisar su casa que ha sido asaltada. En ella guardaba las cenizas de su pequeño hijo fallecido (Niqui/Govinda). Ambas historias se entrecruzan mientras que "el Francés" adopta parte del protagonismo como interlocutor de la misma:

Hace un rato, mientras G. se concentraba en la muerte de su abuela, pensaba que debía existir una conexión misteriosa entre lo que escribía y el encuentro con Inés, el viaje, las cenizas [...] Si lograba cerrar ese relato, pensó, terminaba una etapa. Pero ahora se daba cuenta de que la vida no ofrece finales y principios delimitados como una narración. La vida es un continuo [...] Y son raras las veces en que uno consigue establecer finales y principios que, por lo general, no son otra cosa que la prolongación oculta de una experiencia pasada que se resiste a morir. (88)

La tercera parte de la novela concluye y retorna a modo de epílogo bajo el título de "Réquiem". Escrita en primera persona, conecta los tiempos pasado y presente, retomando de nuevo algunas de las informaciones y acciones acontecidas en la segunda parte. Saccomanno regresa al relato familiar, reanudando la agonía de la abuela enferma y la incapacidad del padre sometido a un triste final. El relato prosigue con el transcurso de la adolescencia y la juventud arrolladora de G. que ingresa en una agencia de publicidad mientras que estudia de noche, militando en una agrupación trotskista. Una narración tamizada a su vez por la tumultuosa historia de la nación.

El joven revela sus descubrimientos literarios y políticos, reflejando un periodo exaltante, pleno de curiosidades e intereses culturales, enfrentado al padre: cautivado, estancado en su "propio personaje" y agotado por la coyuntura sociopolítica argentina. Así pues las relaciones paterno-filiales se verán extinguidas tras su entrada en la Universidad, alejándose de los gustos paternos instituidos, al sentirse atraído por géneros literarios menores y marginales. La tensión familiar se verá exacerbada con la llegada de los militares al poder (1976), cuando el padre, rozando el sueño de dedicarse a la escritura, es trasladado a un puesto subalterno en el barrio de origen familiar, donde parece ocultarse tras una historia que le ensombrece:

Me preguntaba entonces si para mi padre ser escritor, publicar un libro, no probaba algo. Que su nombre y apellido aparecieran en la cubierta de un libro era una especie de título. Y una manera de limpiar el pasado [...]

En 1976 los militares asaltaron nuevamente el poder. Mi padre temía perder su puesto. Pasados los cincuenta años, a una edad en que no se consigue trabajo fácilmente, mi padre se resistía a renunciar abandonando la seguridad de un sueldo a fin de mes, un sueldo que, según él, le había permitido escribir, ser alguien. Era la primera vez, según sus palabras, que agachaba la cabeza [...] Al sancionarlo, lo despacharon a una repartición de suministros, una oficina de Mataderos. La suerte lo devolvía al barrio en que había nacido, el barrio de cuya influencia había querido librarse, según él mediante su afán de superación. Entonces sufrió su primera isquemia. Poco después 
la segunda [...] Al devolverlo al barrio, el sumario, la sanción y el desplazamiento lo devolvían también a aquella humillación de haber sido detenido por el robo de aquel sombrero. (102-104)

El final de la novela recupera el argumento central del texto: la familia en relación a la construcción de la nación, el sufrimiento de sus componentes por la enfermedad -el aislamiento y el dolor al que arrinconan a sus víctimas- y por último la muerte esperada, su peso, nunca concluida o resuelta cuando la enfermedad llega a su fin. El protagonista (G.) trama el des-apego familiar partiendo simbólica y físicamente de un punto de arranque: una historia personal, el paisaje de una estación de autobús en una noche helada, la herencia del pensamiento judeocristiano en los pobres. Y ahonda en sus referentes familiares, sus orígenes para poder escribir sobre sí mismo. Pero no lo hará motivado por el hecho de trascender el olvido sino para re-conocerse y pro-seguir, posicionándose en la siguiente paradoja existencial:

Durante los diecinueve años que duró su enfermedad, una y otra vez escribí sobre mi padre, persiguiendo desvelar un misterio. Se escribe buscando una explicación. Y sólo se encuentran incógnitas [...] Los pobres, a pesar de sus indigencias, logran un ascetismo que a los ricos les está vedado [...]. No, no era igual la muerte para los ricos que para los pobres. Y en este aspecto también Dios era injusto, prometiendo un paraíso a los que sufrían. Ante la injusticia, estos tenían que reconfortarse pensando que era cuestión de crecer o reventar, sin haber conocido en vida algo distinto del sufrimiento. Una vida no alcanzaba para pagar una fe. (124-25)

Mediante el recuerdo y el dispositivo de la memoria, Guillermo Saccomanno hace presente un pasado inconcluso, reconstruyéndolo y aireando el peso del mismo, que como tal es siempre complejo explora, desde la resistencia y la trasposición, su identidad. Entre sus logros narrativos cabe mencionar el modo en que sus fragmentos logran en el lector una considerable verosimilitud, sea o no sea verdad lo que esté contando y a pesar de reiterar su opinión sobre que "esto no es literatura". Asimismo la frontera de la dimensión privada y pública se transgrede de manera constante en el relato, pues el autor hace pública su visión de lo personal, lo íntimo. Aunque reconoce el efectivo desgarro entre experiencia y discurso, cuando éste relata su experiencia cercenada, más que lavar su "ropa sucia", recompondrá todo el manto social. Por consiguiente, resuelve con verdadera maestría y hábil atrevimiento, entre otros aspectos, un duelo que parecía hasta entonces postergado. 
El espacio narrativo, ajeno a los fundamentos de la racionalidad científica, ${ }^{19}$ en cuanto a hecho cultural que es el modo en que hemos abordado dicha práctica, redescubre escisiones y revela cuestiones no resueltas por los sujetos estableciéndose una alianza con el lector (Lejeune 61). Los silencios, las ausencias, los posicionamientos definen las condiciones de producción del metadiscurso, desafiando categorías por lo regular naturalizadas; a la vez que mediante dichas modalidades culturales se convoca el ejercicio de la memoria no sólo como sentimiento sino como conocimiento. En este sentido la memoria fluye como vaso comunicante, a través del cual interactúan diversos niveles espacio-temporales. Diversas modalidades de escrituras del yo: autobiografías, diarios, memoria, autoretratos, crónica, narrativas orales, etc., estimulan y recomponen el caótico recuerdo del sujeto transterrado.

El giro subjetivo barajado en El buen dolor se instituye en un territorio de encuentro intercultural, mientras que el mecanismo narratológico actúa como vehículo cohesionador de identidades personales y colectivas. Hemos subrayado los valores que se ponen en alza mediante la presente expresión narrativa con la finalidad de constatar el devenir sociohistórico. En este sentido el discurso del escritor argentino es un espacio explorativo y, por ende, nunca concluyente, sobre la memoria y la identidad como tarea del sujeto transterrado. Dicho de otro modo, este se erige en un lugar de interpelación del yo/nosotros que, en el marco del desplazamiento, rastrea la huella fronteriza de pertenencia y/o exclusión.

Para concluir, la obra El buen dolor del escritor argentino Guillermo Saccomanno es una novela corta que, bajo unas determinadas coordenadas históricas, ahonda en la intrahistoria de una familia de origen hispanoitaliana en la Argentina contemporánea. Profundamente testimonial está pincelada de trazos autobiográficos, mientras que su autor no trama simples argucias memorialísticas contra el olvido, sino que discierne sobre la comprensión identitaria en base al legado sociohistórico de los sujetos. De este modo el protagonista (G.) explora, no sin fricción, una formulación identitaria en continua deriva existencial. Instituciones como la familia y el Estado, en cuanto a dispositivos opresores y/o normalizadores, adquieren un rol vital. Como si de un pacto

\footnotetext{
19 Desde el enfoque narrativo expuesto, los límites de la veracidad de la obra artística literaria y la comprensión del discurso deben enmarcarse en el propio proceso de lectura y no a partir de la locución o la autoría/autoridad científica, que es lo que suele primar en la transferencia de una obra. Desde este enfoque sería irrelevante examinar su exacto reflejo con la realidad o conexión al método científico, puesto que el discurso literario conforma un dispositivo simbólico que estimula la autorreflexión y que carece, en primera instancia, de una situación de referencia respecto a la realidad inmediata. De ahí la propuesta de analizar el texto a partir del transcurso de la lectura donde el lector se convierte en el sujeto de las ideas que se desprende del mismo, percibiendo en cada caso un mundo ajeno que se torna propio. Presupuestos expuesto en Wolfgan.
}

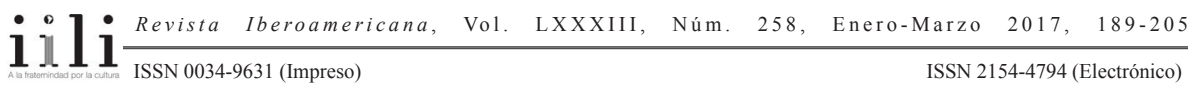


autobiográfico se tratara y otorgando un papel central a la territorialidad fronteriza, el escritor concluye con esta obra un viaje interior donde traspasa en diversos momentos de la obra la frontera entre historia y ficción. A pesar de su posicionamiento en los márgenes del relato, el personaje principal huye de enfoques melancólicos y nostálgicos. Con diestra agilidad discursiva, el autor recompone en estos textos, independientes pero conectados entre sí, diversos tiempos y espacios entrecruzando, adelantando o concluyendo parte de su argumento al lector-investigador.

\section{BIBLIOGRAFÍA}

Althusser, Louis. Ideología y aparatos ideológicos del Estado. 1970. México: Siglo XXI, 1974.

Amorós, Celia. "Notas para una teoría nominalista del patriarcado". Asparkía 1 (1992): 41-58.

Arendt, Hannah. “¿Qué es la autoridad?”. Entre el pasado y el futuro. Ocho ejercicios sobre la reflexión política. 1961. Barcelona: Península, 1996.

Los orígenes del totalitarismo. 1951. Madrid: Alianza Editorial, 1998.

Arfuch, Leonor. Pensar este tiempo: espacios, afectos, pertenencias. Buenos Aires, Barcelona, México: Paidós, 2005.

Binilés, Fina y otros. Filosofía y género. Identidades femeninas. Fina Birulés, comp. Pamplona: Pamiela, 1992.

Broullón, Esmeralda. "El Diario como testimonio de vida: Diario de un emigrante". Descubriendo la Nación en América. Identidades, imaginarios, estereotipos sociales y formas de asociacionismo de los españoles en el Cono Sur. Elda González y Andrea Reguera, coords. Buenos Aires: Biblos, 2009. 105-26.

Brown, Judith K. "Iroquois Women: An Ethnohistoric Note". Toward an Anthropology

of Women. R. Reiter, ed. New York: Monthly Review Press, 1975. 235-51.

Bochenski, Józef Maria. ¿Qué es la autoridad? Introducción a la lógica de la autoridad. Barcelona: Herder, 1979.

Cárcamo, Silvia. "Memoria, realismo y sesgo autobiográfico en Osvaldo Soriano y Guillermo Saccomanno”. Espéculo, Revista de Estudios Literarios 23 (2003): np. Derrida, Jacques. "Fuerza de ley: El fundamento místico de la autoridad". Doxa 11 (1992): 129-91.

Engels, Fiedrich. El origen de la familia, la propiedad privada y el Estado. Madrid: Alianza editorial, 2008.

Foucault, Michel. Introducción. Saber y verdad. Julia Varela y Fernando Álvarez-Uría, trad. Madrid: La Piqueta, 1985.

Fuente Lombo, Manuel de la. "La etnoliteratura como método antropológico". Etnoliteratura. Un nuevo método de análisis en antropología. Manuel Fuente Lombo, coord. Córdoba: Universidad de Córdoba, 1994. 51-72. 
Gaos, José. El transterrado. México, D.F.: Centro de coordinación y difusión de estudios Latinoamericanos, Universidad Nacional Autónoma de México, 2004.

Jiménez Nuñez, Antonio. "Fuentes y métodos de la antropología: consideraciones un tanto críticas". Etnoliteratura. Un nuevo método de análisis en antropología. Manuel de la Fuente Lombo, coord. Córdoba: Servicio de Publicaciones de la Universidad de Córdoba, 1994. 9-49.

Jónasdóttir, Anna. El poder del amor: ¿le importa el sexo a la democracia? Madrid: Feminismos/Cátedra, 1993.

Kuper,Adam. "Lineage Theory:ACritical Retrospect.” Annual Review of Anthropology 11 (1985): 71-95.

Lejeune, Phillipe. El pacto autobiográfico y otros escritos. 1975. Madrid: MegazulEndymión, 1994.

Loureiro, Angel. "La autobiografía y sus problemas teóricos. Estudios e investigación documental". Suplementos Anthropos 29 (1991): 2-8.

Ludmer, Josefina. El cuerpo del delito. Un manual. Buenos Aires: Perfil, 1999.

Molloy, Silvia. Acto de presencia. La escritura autobiográfica en Hispanoamérica. México: FCE, 2001.

El común olvido. Buenos Aires: Norma, 2002.

Muraro, Luisa. "Sobre la autoridad femenina". Filosofía y género. Identidades femeninas. Fina Birulés, coord. Pamplona: Pamiela, 1992.

Rosaldo, Michell. "Mujer, cultura y sociedad: una visión teórica". Antropología y feminismo. Olivia Hernes y Kate Young, comps. Barcelona: Anagrama, 1979. 153-180.

Knowledge and Passion: Ilongot Notions of Self and Social Life. Cambridge: Cambridge UP, 1980.

Rosaldo, Michell y L. Lamphere, eds. Women, Culture and Society. Stanford: Stanford UP, 1974.

Robichaux, David. Familia y diversidad en América Latina. Estudios de casos. Buenos Aires: CLACSO, Consejo Latinoamericano de Ciencias Sociales, 2007.

Saccomanno, Guillermo. El buen dolor. Buenos Aires: Booket, 2008.

Salazar, José Miguel. Identidades nacionales en América Latina. Caracas: Fondo editorial de Humanidades y Educación; Universidad Central de Venezuela, 2001.

Sarlo, Beatriz. Tiempo pasado. Cultura de la memoria y giro subjetivo. Una discusión. 2005. Buenos Aires: Siglo XXI, 2007.

Sennett, Richard. La autoridad. Madrid: Alianza, 1992.

Smith, Raymond Th. "The Matrifocal Family." The Character of Kinship. Jack Goody, ed. Cambridge: Cambridge UP, 1973. 121-44.

Yanagisako, Sylvia. "Family and Household: The Analysis of Domestic Groups." Annual Review of Anthropology. Stanford: Stanford UP, 1979.

Wolfgang, Iser. El acto de leer. Madrid: Taurus, 1976.

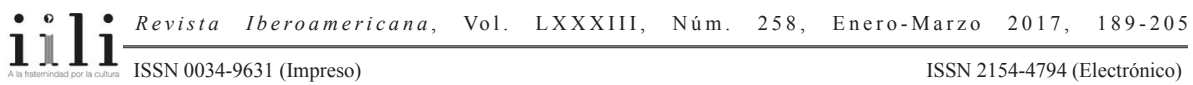


